\title{
Writing Instruction: What Is Being Taught in Japanese High Schools, Why, and Why It Matters
}

\section{Bern Mulvey}

Iwate University

Citing continuing poor performance on diagnostic texts, MEXT has recently advocated for an increased emphasis on academic English, particularly writing instruction (to include critical thinking). However, little sustained attention has been given to the specifics of what is being taught now, how, and why. In this paper, I present recent national survey results and observations made during six years of teaching both Japanese and English academic writing to Japanese students at two Japanese universities. The national survey results support my own observations, suggesting that-and in direct contrast to prevailing beliefs about the curriculum-many Japanese students struggle to write logically and persuasively in English for the same reason they struggle in Japanese: because nobody yet has taught them how. Accordingly, in order to improve academic English skills, critical reading and writing skills in the L1 need development also-where possible, in conjunction with similar emphases in the L2 classes, and ideally including collaboration among all the teachers providing this instruction.

近年、文部科学省は診断調査 (TOEFL、PISAなど) における継続的な 成績不振を受け、国際的に質の高い英語力を目指すためのアカデミック・ イングリッシュ、特に批判的思考力を含んだ学術的ライティングの指導の 強化を求めている。しかし、日本の大学・高校におけるライテイング指導 の現状について、何が、どのように、なぜ教えられているのかといったよう な詳細に対しては、何ら評価・分析が行われていないのが実情である。本 論文では、6年間にわたり二つの大学で日本人学生を対象とした英語・日 本語でのアカデミック・ライティング指導の経験をもとに、最近発表され た調査結果を検討し、日本におけるアカデミック・ライテイング指導の現 状および今後の課題について研究を行つた。「読み・書きの指導が非常 に重視されている」とよく言われる日本の国語・英語教育だが、英語に限 らず母語においても、その方法を学生に指導してこなかつたせいで、作文 カが未だに乏しい状態であることが分かった。英語のアカデミック・ライ ティングの力を向上させるには、母語においても批判的な読解力、ライテ イング力を磨くことが必要であり、国語と英語の教員が協力し合って、こ ういった力を育てる必要性を論じる。

$\mathrm{n}$ this article, $\mathrm{I}$ discuss the systemic weaknesses in the high school writing instruction students receive in Japan which make mastery of this important communicative form even more challenging for students. While hundreds of critical studies of English classroom content and pedagogy in this country exist, the overwhelming focus in the critical literature has been on oral communication skills. In comparison, writing instruction has enjoyed a privileged existence, at least partly because of the pervasiveness of the Japanese know grammar, reading, and writing but cannot speak stereotype (see Mulvey, 1999, 2001; Ueno, 2009). Another contributing factor to the lack of recent critical studies includes a series of influential articles by Kubota $(1997,1998,1999)$ and Kubota and Lehner $(2004,2005)$ discussing Japanese and English academic writing education in high school and college settings in Japan. These articles describe a pattern of study and mastery of L1 rhetorical forms in Japanese high schools, including extensive exposure to writing which incorporates "unity created by a clear theme, logical development of ideas, and placing a topic sentence at the beginning of a paragraph" (Kubota, 1998, p. 472) - the so-called academic English format.

The impact of the Kubota and Lehner articles on the field of contrastive rhetoric cannot be overstated. Connor $(2002,2005)$ has written about this impact extensively. However, as I will discuss, their characterizations of writing education in Japanese and English in academic settings in Japan suggest a high mastery level (including metacognitive awareness) of rhetorical forms in the L1 and extensive exposure to the $\mathrm{L} 2$-claims that are contradicted by extensive nationwide surveys and other research. Accordingly, in this article I intend to identify the problem, as well as call for more informed discussion and collaboration on possible solutions.

\section{Literature Review}

As alluded to above, the idea persists that Japanese students are mastering English reading and writing skills at the expense of listening and speaking. Mulvey $(1999,2001)$ lists numerous articles articulating this position, with Yamaoka (2010) one of several more recent examples. Most of these studies assert that this prioritizing of reading and writing skills over listening and speaking is the result of a washback effect from university entrance exams. Still, Kubota and Lehner have argued that another reason is the supposedly powerful Western (spe- 
cifically American) influence on writing pedagogy in this country. Their oft-cited claims include the following:

1. There has historically (dating back to the Meiji era) been a strong "Western influence on teaching writing" in Japan (Kubota, 1997, pp. 472, 477).

2. This influence has continued after World War Il to the point that "English composition theories constitute the basis of the study of composition and rhetoric" (Kubota, 1997, p. 472).

3. Japanese student writers are taught to model writing structure on English rhetorical patterns (Kubota \& Lehner, 2004, pp. 11, 19).

4. The "global homogenization of language and culture" caused by "the spread of English and American culture" has led directly to the othering of Japanese writing (Kubota \& Lehner, 2004, p. 20).

Again, it is important to emphasize that their assertions refer to writing in both the $\mathrm{L} 1$ and the $\mathrm{L} 2$. They contend that due to Western (though again, chiefly American) influence on both pedagogy and written rhetorical forms, even Japanese writing has come to privilege ostensibly English forms and structures. Finally, they feel that the resultant emphasis on mastering academic English organizational strategies has "tended to avert teachers' and researchers' attention from second language writers' writing ability and experience in their native language" (Kubota \& Lehner, 2004, p. 19), resulting in what they term "assimilationist teaching" (Kubota \& Lehner, 2004, p. 20).

Both these authors advocate instead a "critical contrastive rhetoric" that "challenges deficit, assimilationist, and essentialist orientations in teaching, responding to, and assessing ESL and EFL writing" (Kubota \& Lehner, 2004, p. 20). Finally, they argue for "reflexive engagement" in the EFL classroom, where groups of students who share the same language background can "engage in a deeper dialogue in their $\mathrm{L} 1$ about their positionings in relation to L1 and L2 writing" (Kubota \& Lehner, 2004, p. 19). Engagement is seen as crucial to stemming the ostensibly assimilationist trend in Japanese high school writing pedagogy, or as they write, "a significant goal of an English writing course (ESL or EFL) is the addition of new and different ways of writing rather than the subtraction of ways a teacher might find inappropriate or lacking" (Kubota \& Lehner, 2004, p. 21).

\section{What Is Being Taught}

The reality is that little research exists to support the above claims. First, as the Ministry of Education (MEXT, 2005a), Nishijima (1995), and Ueno (2009) demonstrate, there is no evidence that Japanese students are better at reading and writing. On the contrary, PISA and TOEFL test scores typically identify reading and writing as areas of comparative weakness, with Japanese generally faring better in listening (e.g., see MEXT, 2005a; Educational Testing Service, 2010, p. 9). Moreover, MEXT recently published additional statistics documenting the continuing poor performance by Japanese high school students when writing in English, stating that writing, along with speaking, are the major, ongoing areas of concern (2016). Finally, as Guest $(2000,2008)$ and Mulvey $(1999,2001)$ discuss in some detail, evidence of a washback effect-positive or negative-from university entrance exams on high school English pedagogy is actually scant. For example, it has been shown exhaustively that for the overwhelming majority of Japanese students, high school English classes do not offer instruction in reading and writing skills sufficient to prepare them for the pertinent sections of these examinations. Indeed, the lack of a washback effect prompted MEXT to release the following statement:

A number of high school educators continue to hold the opinion that, until the entrance examinations change, the curriculum cannot be changed. Well, we would like them to understand that, both with the Center exam and the individual university entrance exams, extensive reforms have been ongoing for some time. $(\mathrm{MEXT}, 1999)^{1}$

Moreover, MEXT has responded to the ongoing unwillingness of high school teachers to adjust to changing exam contents by mandating English-medium classroom instruction and a greater focus on critical thinking and academic English writing skills (e.g., see MEXT 2004a, 2004b, 2005a, 2005b, 2009, 2010, 2012a).

Many of the assertions by Kubota and Lehner are similarly contradicted by research. Interestingly enough, Kubota and Lehner $(2004,2005)$ repeatedly cite Hirose (2003) in support of their position that "the rhetorical patterns employed by Japanese writers and recommended by writing specialists in Japan increasingly model after English" (e.g., Kubota \& Lehner, 2004, p. 19). However, while the Hirose study does suggest that some Japanese student writers may value so-called Western rhetorical strategies, Hirose devotes most of the article to asserting a position identical to my own: 
In regard to L1 writing instruction, Japanese students do not generally receive any formal L1 expository or academic writing instruction at any level of Japanese education. They have the most writing experience in expressive writing (writing about their experiences in journals/ diaries), summaries and kansoubun (personal impressions) of materials read, and the least in expository and argumentative writing at school. (2003, p. 183)

For example, as a Japanese who was born and received education up to graduate school level in Japan, I have not taken a single L1 writing course, and other Japanese bilingual academics share this background (Hirose, 2003, p. 184).

Regarding L2 English writing, Japanese students' experience is practically non-existent. L2 writing instruction in high school is oriented toward translation from L1 to L2 at the sentence level. (Hirose, 2003, p. 184)

In other words, Hirose's observations actually appear to refute the central premise articulated in the Kubota and Lehner articles which cite it.

The accuracy of the Hirose comments is further supported by Mok (1993), MEXT (2004b, 2005a, 2005b, 2010), Mulvey (1999, 2001), and Takagi (2001), all of whom suggest that academic writing-both in the L1 and L2-is not taught in most Japanese high schools. Instead, the traditional focus has been on emotive free writing in Japanese and on teacher-centered classes featuring grammar-translation in English. This latter observation echoes the findings of several recent surveys, including the massive MEXT survey of 2011 that received responses from 218 high schools in 45 prefectures (MEXT, 2012b). In the 2011 survey, Japanese teachers of English were asked to describe in detail their pedagogy choices, including materials and assignment or learning activity types for multiple categories of English classes. The chart below delineates usage rates for the following activities in English writing classes.

Table 1. Usage Rates by Activity Type in High School English Writing Classes (MEXT, 2012b, p. 73)

\begin{tabular}{lcccc}
\hline & Listening & Speaking & Reading & Writing \\
\hline Usually & 22 & 9 & 31 & 71 \\
Sometimes & 30 & 31 & 36 & 17 \\
Rarely & 30 & 28 & 15 & 3 \\
Never & 20 & 23 & 9 & 1 \\
\hline
\end{tabular}

Given that these are writing classes, low percentages in listening and speaking activities are to be expected. However, it is telling that over $20 \%$ of teachers report that their writing classes often include no writing. More significantly, later in the same study, only $20 \%$ of writing classes report "essay writing" as a frequent activity; in contrast, over $40 \%$ report little to no essay writing over the course of an academic year. Instead, writing class activities overwhelmingly tend to be line-byline Japanese-English translation exercises, with grammatical explanation of these isolated sentence translations taking up most of the class periods (MEXT 2012b, p. 77; see also MEXT 2010; Yamamoto, 2012). Finally, while there is some evidence (Mulvey \& Ogawa, 2015) that writing textbooks include academic English-style models for students, there is little evidence that these textbooks are in wide use-for example, according to MEXT (2006), just $19.2 \%$ of all high school students use a writing textbook in their classes.

Here, it is important to reiterate that a similar pattern is found in L1 writing instruction. Essay organizational strategies, recognizing and applying critical analysis, and using factual or scholarly support for opinions are not covered in the typical Japanese high school classroom. Instead, class time is usually devoted to practicing kanji, learning yojijukugo (four-character idioms), kojiseigo (idioms derived from historical events or classical literature), and reading and translating classical literature into contemporary Japanese (Mulvey \& Ogawa, 2015; MEXT, 2004b, 2005b). The results, according to MEXT, are multiple areas of L1 weaknesses, particularly an inability to think independently and present logical opinions, the inability to respond articulately and appropriately to differing objectives and situations, and the inability to read and understand texts accurately regardless of task (2004a, 2005a). However, as Hirose notes (2003, p. 184), some university-bound high school students take shoronbun (Japanese essay writing) classes as an additional elective which are taught on a rotational basis by that year's tannin [head teacher]. However, in these cases, there is often no set curriculum. Significantly, MEXT sees the lack of a set curriculum as a systemic problem with L1 instruction, writing "first we need to reexamine what type of Japanese essay structure and language usage should be used as models" (2005b). ${ }^{2}$ Keep in mind that many Japanese universities have instituted Japanese writing classes for the incoming students in response (Mulvey, Winskowski, \& Comer, 2011).

In other words, there seems to be no evidence of systemic, cohesive academic writing instruction at 
the high school level, either in the L1 or L2. This finding matches directly with my experiences as a university teacher of both Japanese and English academic writing. In surveys conducted over six years at lwate National University and Iwate Prefectural University, only $10 \%$ of over 300 students who took my classes had received high school instruction in thesis statements, introductory and/or concluding paragraph roles, and other traditional elements of academic English essay writing. None had written formal argumentative papers-in Japanese or English-delineating a unique argument based on their own critical analysis of a text and utilizing quotes or citations to support that argument. Almost half (46\%) of the students were initially unfamiliar with citation conventions in Japanese. Finally, over half (51\%) had no knowledge of basic paragraphing conventions in English, including students placing line breaks after each sentence and/ or indenting randomly-sometimes even within a sentence.

\section{Causes}

The idea that many Japanese students receive instruction in English academic writing prior to university is a myth; indeed, few will receive such instruction in their L1. Moreover, MEXT recognizes this and has instituted various policies in response. Since 2008, official government policy has promoted eigo o tsuujite (learning through English) -in other words, the usage of English as a tool for academic discovery-with MEXT enacting 18 new initiatives to help ensure this happens (e.g., MEXT 2005a, 2005b, 2008, 2010, 2012a, 2012b). In high schools, this means in theory that English is no longer to be taught in isolation, mainly for university entrance and in classes featuring lecture, rote memorization, and line-by-line translation methodologies. Instead, language classes are to become "communicative" and focused on critical thinking and academic English skills.
However, despite its good intentions, MEXT fails to address two important reasons for the continuing usage of ineffective or inappropriate writing pedagogy: class sizes and teacher training.

As can be seen in Table 2, 61\% of high school writing classes in Japan have between 31 and 40 students, with another 10\% averaging between 26 and 30 students. In contrast, academic writing classes in the United States tend to be below 20 students for "regular" (i.e., instruction by English native speakers) writing classes, and 15 students for ESL classes (Haswell, 2015). In other words, Japanese instructors teaching academic English writing in Japan are doing so with class sizes usually double, and often nearly triple, that of their ESL counterparts in the United States. Indeed, a hypothesis can be made that one reason teachers do not address academic structural conventions in these writing classes is that they lack the time to do so.

Furthermore, as Mulvey (1999) and Takagi (2001) note, there are questions about the preparation teachers receive before being given these classes. For example, academic writing in English is an elective in most university programs. Also, even in these classes, some teachers still use grammar-translation to teach English writing (Takagi, 2001, p. 6). Finally, and perhaps accordingly, when compared to their native English speaker colleagues, there is evidence that Japanese teachers tend to give more comments overall and judge grammatical errors more harshly in their students' writing (Hijikata-Someya, Ono, \& Yamanishi, 2015; Schmitt, 1993). In combination with the large class sizes, the result is that they can generally comment far less on organizational issues. Conversely, any realistic reform proposal must address these issues as well.

\section{Conclusion}

What does this mean for our writing classes? First, it means that the "reflexive engagement" advocated by Kubota and Lehner is almost invariably impos-

Table 2. Average Class Size by Type (MEXT 2012b, p. 68)

\begin{tabular}{|c|c|c|c|c|c|c|}
\hline Class size $\quad$ Class type & Oral I & Oral II & Eigo I & Eigo II & Reading & Writing \\
\hline $31-40$ & $46 \%$ & $35 \%$ & $67 \%$ & $71 \%$ & $75 \%$ & $61 \%$ \\
\hline $26-30$ & $12 \%$ & $8 \%$ & $14 \%$ & $11 \%$ & $12 \%$ & $10 \%$ \\
\hline $21-25$ & $7 \%$ & $6 \%$ & $7 \%$ & $8 \%$ & $5 \%$ & $10 \%$ \\
\hline $16-20$ & $31 \%$ & $35 \%$ & $7 \%$ & $6 \%$ & $5 \%$ & $9 \%$ \\
\hline $11-15$ & $1 \%$ & $8 \%$ & $1 \%$ & $1 \%$ & $1 \%$ & $2 \%$ \\
\hline 10 & $0 \%$ & $8 \%$ & $0 \%$ & $0 \%$ & $0 \%$ & $0 \%$ \\
\hline
\end{tabular}


sible, as students lack the L1 and L2 writing background necessary to participate in such discussions. Secondly, there is a demonstrated need to provide basic instruction in how to organize, and to present one's arguments or exposition in ways conducive to achieving persuasion and understanding-including providing typical structures for introductions and conclusions, paragraphing conventions, and training in the use of quotations. Writing classes, as well as pedagogical instruction for teachers, should include discussion of what constitutes persuasive argument in English and in Japanese.

Furthermore, while admirable in their intent, the MEXT proposals for the introduction of TOEFL testing, critical thinking, textual analysis, and academic writing in Japan's high schools and universities can work only with a realistic understanding of how unprepared most Japanese high school students currently are for such testing and instruction. Unfortunately, informed debate addressing this reality is often missing from the general discussion. Worse, the attitudes and efforts of the so-called "underperforming" students are often criticized, as if they are to blame for their evident deficiencies in required skill areas. As should be clear from the above, many students here struggle to read critically and write logically and persuasively in English for the same reason they struggle in Japanese: because nobody has taught them how.

Finally, this is not something solvable merely by adding more "oral communication" classes to the English curriculum. Among other things, critical reading and writing skills in the L1 need development also-where possible, in conjunction with similar emphases in the L2 classes-and ideally should include collaboration among all the teachers providing this instruction.

\section{References}

Connor, U. (2002). New directions in contrastive rhetoric. TESOL Quarterly, 36, 493-510.

Connor, U. (2005). Comment by Ulla Connor. Journal of Second Language Writing, 14, 132-136.

Educational Testing Service. (2010). Test and score data summary for TOEFL Internet-based and paper-based tests, January 2009-December 2009 test data.

Guest, M. (2000). "But I have to teach grammar!”: An analysis of the role "grammar" plays in Japanese university English entrance examinations. The Language Teacher, 24(11), 23-29.

Guest, M. (2008). Japanese university entrance examinations: What teachers should know. The Language Teacher, 32(2), 15-19.
Haswell, R. (2015, October). Class sizes for writing coursesregular, advanced, honors, and basic. Retrieved from <http://comppile.org/profresources/classsize.htm>

Hijikata-Someya, Y., Ono, M., \& Yamanishi, H. (2015). Evaluation by native and non-native English teacher-raters of Japanese students' summaries. English Language Teaching, 8(7), 1-12.

Hirose, K. (2003). Comparing L1 and L2 organizational patterns in the argumentative writing of Japanese EFL students. Journal of Second Language Writing, 12, 181-209.

Kubota, R. (1997). A reevaluation of the uniqueness of Japanese written discourse implications for contrastive rhetoric. Written communication, 14, 460-480.

Kubota, R. (1998). An investigation of L1-L2 transfer in writing among Japanese university students: Implications for contrastive rhetoric. Journal of Second Language Writing, 7, 69-100.

Kubota, R. (1999). Japanese culture constructed by discourses: Implications for applied linguistics research and ELT. TESOL Quarterly, 33, 9-35.

Kubota, R., \& Lehner, A. (2004). Toward critical contrastive rhetoric. Journal of Second Language Writing, 13, 7-27.

Kubota, R., \& Lehner, A. (2005). Response to Ulla Connor's comments. Journal of Second Language Writing, 14 137-143.

MEXT. (1999). Dai 5 shō: Shotō chūtō kyōiku to kōtō kyōiku to no renzoku o jūshi shita nyūgakusha senbatsu no kaizen. [Chapter 5: On improving student selection methods to allow greater consideration of the connections between primary/secondary and postsecondary education]. Retrieved from <http://www.mext.go.jp/b_ menu/shingi/old_chukyo/old_chukyo_index/toushin/ attach/1309753.htm>

MEXT. (2004a). Eigo ga tsukaeru nihonjin no ikusei no tame no kōdō keikaku [Action plan to cultivate Japanese who can use English]. Retrieved from <http://www. mext.go.jp/b_menu/shingi/chukyo/chukyo3/004/ siryo/04031601/005.pdf>

MEXT. (2004b). Korekara no jidai ni motomerareru kokugoryoku ni tsuite [On the Japanese skills necessary for the new age]. Retrieved from <http://www.mext.go.jp/b_ menu/shingi/bunka/toushin/04020301/015.pdf>

MEXT. (2005a). Dokkairyoku kōjō puroguramu [Program for improving critical reading skills]. Retrieved from <http://www.mext.go.jp/a_menu/shotou/gakuryoku/ siryo/05122201/014/005.pdf>

MEXT. (2005b). Kyōiku katei bukai (Dai 3 ki Dai 1-12 kai) ni okeru omona iken [Key opinions given at the education program meetings (The third term/1st-12th meetings). Retrieved from < http://www.mext.go.jp/b_menu/ shingi/chukyo/chukyo3/004/siryo/05111603/01.htm>

MEXT. (2006). Kōtō gakkō gaikokugoka no kaku kamoku no kaisetsu jōkyō oyobi kyōkasho no juyō sassū [The current situation regarding foreign language class offerings and textbook usage numbers]. Retrieved from <http:// www.mext.go.jp/b_menu/shingi/chukyo/chukyo3/004/ siryo/07092002/004/003.htm> 
MEXT. (2008). Shisaku mokuhyō 4-1: Daigakutō no kokusaika ya kyōiku kenkyū no shitsuno kōjō/hoshō no suishin [Policy goals 4-1: Internationalizing universities and improving/guaranteeing better quality education and research]. Retrieved from <http://www.mext.go.jp/a_ menu/hyouka/kekka/1285673.htm>

MEXT. (2009). Kōtō gakkō gakushū shidō yōryō kaisetsu: Gaikokugo hen, Eigo hen. [An explanation of the changes to high school instruction: Foreign languages section]. Retrieved from <http://www.mext.go.jp/ component/a_menu/education/micro_detail/__ icsFiles/afieldfile/2010/01/29/1282000_9.pdf>

MEXT. (2010). Eigo shidō hōhō tō kaizen no suishin ni kannsuru kondankai [Meeting to discuss ways to promote the improvement of English language instruction]. Retrieved from <http://www.mext.go.jp/b_menu/ shingi/chousa/shotou/018/toushin/010110b.htm>

MEXT. (2012a). Daigaku kaikaku jikkō puran [University reformation action plan]. Retrieved from <http://www. mext.go.jp/b_menu/houdou/24/06/__icsFiles/afieldfi le/2012/06/05/1312798_01_3.pdf>

MEXT. (2012b). 4. Shitsumonshi chōsa kekka (seito shitsumonshi/gakkō shitsumonshi) [Section 4. Results from the questionnaire (student questionnaire/ school questionnaire)]. Retrieved from <http://www. mext.go.jp/a_menu/kokusai/gaikokugo/_icsFiles/ afieldfile/2013/03/28/1332393_2.pdf>

MEXT. (2016). Heisei 26 nenndo eigoryoku chōsa kekka (kōkō 3 nensei) no gaiyō (shōsaiban) [Detailed outline of the results for the 2015 survey of English ability (3rd year high school students)]. Retrieved from <http:// www.mext.go.jp/component/a_menu/education/ detail/_icsFiles/afieldfile/2015/07/03/1358071_02.pdf>

Mok, W. E. (1993). Contrastive rhetoric and the Japanese writer of EFL. JALT Journal, 15(2), 151.

Mulvey, B. (1999). A myth of influence: Japanese university entrance exams and their effect on junior and senior high school reading pedagogy. JALT Journal, 21, 125-142.

Mulvey, B. (2001). The role and influence of Japan's university entrance exams: A reassessment. The Language Teacher, 25(7), 11-17.

Mulvey, B., \& Ogawa, H. (2015). L1 and L2 writing skills: Notes from a unique teaching collaboration. Studies on European and American Languages and Cultures, 2, 175-190.

Mulvey, B., Winskowski, C., \& Comer, K. (2011). University accreditation developments in Japan: Matching or moving beyond the US process? Higher Education Policy, 24, 535-553.

Nishijima, H. (1995). Nihonjin no jakuten wa nanika [What are the weak points in the English abilities of Japanese?]. Eigo Kyouiku, 44, 28-30.

Schmitt, N. (1993). Comparing native and nonnative teachers' evaluations of error seriousness. JALT Journal, 15, 181-191.

Takagi, A. (2001). The need for change in English writing instruction in Japan. The Language Teacher, 25(7), 5-10.
Ueno, T. (2009). Nihongo bokokugowasha ha naze TOEFL no tokuten ga hikui no ka: Riyu no kōsatsu to eigo gakushūhō no ichiteian. [Why are Japanese TOEFL scores so low? An examination of the reasons and a suggestion for improvement]. The Journal of the Department of Social Welfare, 12(3), 157-166.

Yamamoto, K. (2012). Kōtōgakkō ni okeru toppu-daunshiki eigo jugyō: Bumpō/yaku/setsumei no lgi. [On the role of grammar-translation in the English classroom]. Aichi Shukutoku Daigaku Daigakuin Eibun Gakkai, 21, 1-17.

Yamaoka, K. (2010). The current situation and future prospects of Japanese English education. Ritsumeikan Gengo Bunka Kenkyūjo, 22(1), 59-66.

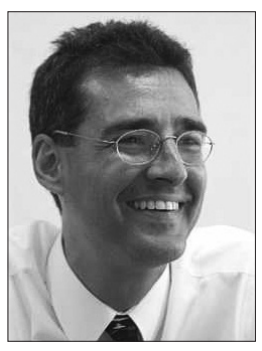

Bern Mulvey is a professor at Iwate National University. His most recent book was published by Oberlin College Press in 2014. His articles and essays have appeared, among other places, in Higher Education Policy, Japan Studies Review, American Language Review, Continuing Higher Education Review, JALT Journal, Nibutani Ainugo Kyoshitsu, Times Higher Education Supplement, and Asahi Shinbun.

\section{(Endnotes)}

1. 高等学校関係者の中には,「大学入試が変わらなけ れば高校教育は変われない」という意見もあるが, 大 学全体としても, 個々の大学においても鋭意改革が 進められている状況を十分理解してほしい

2. どのような文章, 表現がモデルとして使われるべき か, 望ましい国語力を見直すことが必要”
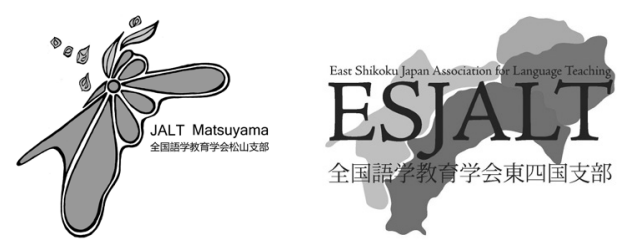

\section{7th Annual Shikoku JALT Conference}

Sponsored by Matsuyama JALT, East Shikoku JALT, and Oxford University Press

Saturday, June 18 (1:00-5:30) Ehime University

Keynote Speaker: John Adamson Research into Academic Publishing: Emerging Trends and Practices

Plus many other great presentations! 